
RESEARCH AND DEVELOPMENT

\author{
http://journal.unnes.ac.id/sju/index.php/higeia
}

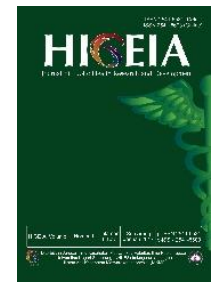

\title{
KEJADIAN KATARAK SENILIS DI RSUD TUGUREJO
}

\author{
Anni Nur Aini ${ }^{\bowtie}$, Yunita Dyah Puspita Santik
}

Epidemiologi dan Biostatistika, Jurusan Ilmu Kesehatan Masyarakat, Fakultas Ilmu Keolahragaan, Universitas Negeri Semarang

\section{Info Artikel}

Sejarah Artikel:

Diterima Februari 2018

Disetujui Maret 2018

Dipublikasikan April

2018

\section{Keywords:}

Risk Factors, Age, Cataract Senilis

\begin{abstract}
Abstrak
Angka kejadian katarak senilis di RSUD Tugurejo pada tahun 2014 sebanyak 519 orang, pada tahun 2015 meningkat menjadi 674 orang, dan pada tahun 2016 sebanyak 572 orang. Tujuan penelitian ini untuk mengetahui faktor-faktor yang berhubungan dengan kejadian katarak senilis di RSUD Tugurejo. Penelitian ini dilakukan pada bulan November 2017. Jenis penelitian adalah observasional analitik studi kasus kontrol dengan sampel sebesar 45 kasus dan 45 kontrol. Instrumen yang digunakan adalah lembar kuesioner. Analisis data dilakukan secara univarat dan bivariat dengan menggunakan uji chi-square. Hasil penelitian menunjukkan bahwa p-value umur $(p=0,00)$, jenis kelamin $(p=0,83)$, tingkat pendidikan $(p=0,00)$, tingkat penghasilan $(p=0,02)$, riwayat keluarga katarak $(p=0,45)$, kebiasaan merokok $(p=0,29)$, lama terpapar sinar matahari $(p=0,02)$, dan hipertensi $(p=0,03)$. Simpulan penelitian ini adalah terdapat hubungan antara umur, tingkat pendidikan, tingkat penghasilan, lama terpapar sinar matahari, hipertensi dengan kejadian katarak senilis. Tidak ada hubungan antara jenis kelamin, riwayat keluarga katarak, dan kebiasaan merokok dengan kejadian katarak senilis di RSUD Tugurejo.
\end{abstract}

\begin{abstract}
The incidence of senile cataracts in RSUD Tugurejo 2014 were 519 people, 2015 increased to 674 people, and 2016 were 572 people. This study purposed to determine the factors associated with the incidence of senile cataracts in RSUD Tugurejo. The study was conducted in November 2017. The type of research was case control study with 45 cases and 45 controls. The instrument used is a questionnaire. The Data were analyzed by univariate and bivariate using chi-square test. The results showed $p$-value of age $(p=0,00)$, gender $(p=$ $0,83)$, education level $(p=0,00)$, income level $(p=0,02)$, family history of cataract $(p=0.45)$, smoking habits $(p=0.29)$, long exposure to sunlight $(p=0.02)$, and hypertension $(p=0.03)$. The conclusion of this research is the relationship between age, education level, income level, long exposure to sunlight, hypertension with senile cataract. There was no relationship between sex, family history of cataracts, and smoking habits with the incidence of senile cataracts in RSUD Tugurejo.
\end{abstract}

E-mail: anniaini67@yahoo.com 


\section{PENDAHULUAN}

Katarak adalah pengembangan dari keadaan tidak tembus cahaya dalam lensa. Seiring bertambahnya usia, ada gangguan dalam struktur lensa dan akumulasi pigmen. Katarak ditandai dengan adanya gangguan penglihatan (kabur atau mendung), penurunan tajam penglihatan secara progresif, membutuhkan lebih banyak cahaya untuk melihat hal-hal yang jelas, silau, perubahan persepsi warna dapat terjadi dengan intensitas berkurang, kurangnya kontras atau distorsi kekuningan. Katarak terus berkembang seiring waktu, menyebabkan kerusakan penglihatan secara progresif (Nash, 2013). Jenis katarak yang paling sering ditemukan adalah katarak senilis. Berdasarkan penelitian yang dilakukan oleh Bhardwaj (2016) di Medical College Hospital di India menyebutkan bahwa dari 746 pasien, 53,6\% adalah penderita katarak. Sebagian besar pasien $(55 \%)$ penderita katarak berusia $60-80$ tahun, dan 53,8\% katarak adalah jenis katarak senilis.

Faktor penyebab katarak termasuk katarak senilis dapat berasal dari beberapa faktor yaitu 1) faktor yang tidak dapat dimodifikasi seperti jenis kelamin perempuan dan riwayat keluarga katarak, 2) kondisi medis seperti diabetes, dehidrasi akut, gangguan atopik, hipertensi, asam urat (lebih dari 10 tahun), 3) trauma mata, 4) penyakit mata lainnya, 5) konsumsi obat seperti kortikosteroid, statin, agen topikal yang digunakan dalam pengobatan glukoma, dll serta 6) gaya hidup seperti kebiasaan merokok, paparan sinar matahari, konsumsi alkohol, status gizi (Nash, 2013).

Hasil penelitian Heidar (2015) menyebutkan terdapat hubungan antara lama terpapar sinar matahari dengan kejadian katarak. Sebanyak $64,9 \%$ penderita katarak senilis terpapar sinar matahari selama mereka bekerja, sementara hanya $15,1 \%$ responden kontrol yang terpapar sinar matahari selama bekerja. Menurut Robert (2011) bahwa radiasi UV akut yang intens dan terpapar secara kronis akan menentukan dalam pembentukan katarak yang ditandai dengan mengaburnya lensa mata. Semakin besar intensitas cahaya, maka semakin besar kemungkinan kerusakan mata.

Indonesia merupakan negara dengan angka kebutaan tertinggi kedua di dunia setelah Ethiopia dengan prevalensi di atas $1 \%$. Tingginya angka kebutaan di Indonesia tidak hanya mejadi masalah kesehatan tetapi juga masalah sosial. Berdasarkan data dari World Health Organization (WHO) (2012) katarak merupakan penyebab kebutaan utama di dunia. Terdapat 39 juta orang yang buta di seluruh dunia, dengan penyebab utama kebutaan yaitu katarak sebesar 51\%. Selain itu, katarak merupakan penyebab gangguan penglihatan kedua di dunia dengan angka kejadian sebesar 33\% (Kemenkes RI, 2014).

Berdasarkan Riset kesehatan Dasar (RISKESDAS) Indonesia tahun 2007 dan 2013, prevalensi penduduk yang menderita katarak termasuk katarak senilis di Indonesia sebesar 1,8\% (Kemenkes RI, 2007). Pada tahun 2013, prevalensi katarak semua umur sebesar 1,8\% atau sekitar 18.499 .734 orang. Sementara perkiraan insidensi katarak sebesar $0,1 \%$ per tahun. Selain itu, penduduk Indonesia juga memiliki kecenderungan menderita katarak 15 tahun lebih cepat dibandingkan penduduk di daerah subtropis (Kemenkes RI, 2013).

Berdasarkan hasil Riset Kesehatan Dasar (RISKESDAS) Provinsi Jawa Tengah tahun 2007 dan 2013, presentase penduduk yang terdiagnosis katarak termasuk katarak senilis mengalami peningkatan sebesar $1,1 \%$ yakni pada tahun 2007 dengan prevalensi 1,3\% (Kemenkes RI, 2007) dan pada tahun 2013 prevalensi katarak meningkat menjadi 2,4\%. Selain itu, pada tahun 2013, Provinsi Jawa Tengah merupakan salah satu provinsi yang memiliki prevalensi katarak diatas angka nasional $(1,8 \%)$ dan merupakan provinsi dengan jumlah kebutaan terbanyak di Indonesia dengan penyebab utama kebutaan adalah katarak (Kemenkes RI, 2013).

Berdasarkan laporan dari sub bidang pelayanan kesehatan Dinas Kesehatan Kota 
Semarang mengalami fluktuatif. Pada tahun 2014 jumlah penderita katarak senilis sebanyak 194 penderita. Pada tahun 2015 penderita katarak senilis mengalami peningkatan sebesar 549 menjadi 734 penderita. Pada tahun 2016 penderita katarak senilis mengalami penurunan menjadi 593 penderita.

Rumah Sakit Umum Daerah (RSUD) Tugurejo Semarang merupakan Rumah Sakit Kelas B milik Pemerintah Provinsi Jawa Tengah, yang terletak di Semarang bagian barat. Katarak senilis merupakan jenis katarak yang paling banyak dialami pasien yang berkunjung ke RSUD Tugurejo baik rawat jalan maupun rawat inap. Pada tahun 2016 jumlah kunjungan katarak sebanyak 1817 orang dengan 56,5\% merupakan penderita katarak senilis. Sedangkan pada pasien rawat inap, pada tahun 2016 dari 115 kunjungan katarak, 73\% adalah penderita katarak senilis.

Berdasarkan data rekam medis RSUD Tugurejo menunjukkan bahwa angka kejadian katarak senilis mengalami peningkatan dari tahun 2014 sampai 2016 baik pasien rawat jalan maupun rawat inap. Pasien rawat jalan meningkat sebesar 28 pasien, sedangkan rawat inap meningkat sebesar 23 pasien. Jumlah penderita katarak senilis rawat jalan tahun 2014 sebesar 460 meningkat menjadi 576 pada tahun 2015 dan menurun menjadi 488 pada tahun 2016. Sementara itu, jumlah penderita katarak senilis rawat inap tahun 2014 sebesar 59 meningkat menjadi 98 pada tahun 2015 dan menurun menjadi 84 pada tahun 2016.

Berdasarkan studi pendahuluan tentang distribusi penderita katarak senilis rawat jalan dan rawat inap tahun 2016 di RSUD Tugurejo menyebutkan bahwa $57 \%$ penderita katarak senilis berjenis kelamin perempuan. Sedangkan berdasarkan umur responden, usia 45-64 tahun sebesar $56,8 \%$, dan pada usia 65 tahun keatas sebesar 42,6\%. Distribusi responden berdasarkan pendidikan yang diambil dengan sampel 213 responden yaitu, 8,69\% tidak sekolah, 24,5\% SD, 15,8\% SMP, 44,3\% SMA, dan $10,67 \%$ pendidikan perguruan tinggi. Berdasarkan jenis pekerjaan, dari 141 responden, $64,5 \%$ reponden bekerja diluar gedung seperti wiraswasta, buruh, petani, dll, serta $35,4 \%$ responden bekerja didalam gedung seperti pegawai swasta, PNS, pensiun, IRT, perawat, tidak bekerja. Distribusi responden berdasarkan asal penderita, bahwa sebagian besar responden katarak senilis yang berobat di RSUD Tugurejo adalah responden yang berasal dari 4 kecamatan, yaitu kecamatan Ngaliyan, Tugu, Mijen, dan Semarang Barat. Berdasarkan uraian permasalahan diatas peneliti bertujuan untuk mengetahui faktor-faktor yang berhubungan dengan kejadian katarak senilis di RSUD Tugurejo Kota Semarang.

\section{METODE}

Jenis penelitian ini menggunakan metode penelitian kuantitatif menggunakan observasional analitik dengan rancangan penelitian kasus kontrol (case control study). Populasi kasus dalam penelitian ini yaitu semua pasien dengan diagnosis menderita katarak senilis yang berkunjung ke poli mata RSUD Tugurejo Kota Semarang selama rentang waktu Januari-November 2017 dan tercatat dalam rekam medis rumah sakit yakni sebesar 305 orang. Populasi kontrol yaitu semua pasien yang tidak menderita katarak yang berkunjung ke poli mata RSUD Tugurejo Kota Semarang selama rentang waktu Januari-November 2017 dan tercatat dalam rekam medis rumah sakit berjumlah 2771 orang.

Sampel kasus dalam penelitian ini adalah penderita katarak senilis yang memenuhi kriteria inklusi meliputi penderita dengan diagnosis katarak senilis, berumur $\geq 40$ tahun, tercatat dalam rekam medis RSUD Tugurejo periode waktu 2017 sampai waktu dilakukannya penelitian, dan kriteria eksklusi yaitu responden kasus katarak senilis telah 3 kali didatangi tidak berhasil ditemui atau tidak bersedia berpartisipasi dalam penelitian, pada saat penelitian responden sudah pindah rumah atau meninggal dunia, serta responden menderita diabetes dan obesitas.

Sampel kontrol pasien yang berkunjung 
ke poli mata RSUD Tugurejo Kota Semarang dengan diagnosis selain katarak serta pada saat penelitian berlangsung memenuhi kriteria inklusi meliputi umur $\geq 40$ tahun, tercatat dalam rekam medis tidak menderita katarak di RSUD Tugurejo periode waktu 2017 sampai waktu dilakukannya penelitian, dan kriteria eksklusi yaitu pada saat penelitian responden sudah pindah rumah atau meninggal dunia, responden menderita diabetes mellitus dan obesitas.

Besar sampel minimal yang didapat berdasarkan perhitungan sampel minimal adalah sebesar 45 orang. Pengambilan sampel untuk kasus dan kontrol menggunakan perbandingan 1:1, sehingga besar sampel penelitian ini adalah 45 kasus dan 45 kontrol. Jadi, jumlah sampel secara keseluruhan sebesar 90 sampel. Pengambilan sampel dilakukan dengan teknik purposive sampling.

Sumber data dalam penelitian ini yaitu data primer dan data sekunder. Adapun data primer yang diperoleh dari penelitian ini berasal dari hasil pengisian kuesioner oleh responden secara langsung untuk memperoleh data terkait dengan identitas responden seperti nama, umur, pendikan terakhir, pekerjaan, pendapatan, lama terpapar sinar matahari, kebiasaan merokok, riwayat keturunan pernah menderita katarak dan riwayat hipertensi. Data sekunder diperoleh dari rekam medis RSUD Tugurejo berupa jumlah penderita, nama, umur, jenis kelamin, alamat, diagnosis responden, status menderita diabetes serta data tekanan darah responden.

Teknik pengambilan data terdiri dari wawancara dan dokumentasi. Instrumen yang digunakan yaitu kuesioner. Wawancara dengan kuesioner yaitu dilakukan untuk memperoleh data primer dengan menggunakan kuesioner sebagai alat. Data yang akan diambil meliputi status menderita diabetes mellitus, umur, jenis kelamin, tingkat pendidikan, tingkat penghasilan, riwayat katarak dalam keluarga, kebiasaan merokok, lama terpapar sinar matahari, serta adanya riwayat hipertensi. Dokumentasi dalam penelitian ini berbentuk foto serta dokumen pencatatan hasil wawancara selama penelitian dilaksanakan.
Prosedur penelitian ini meliputi tahap pra penelitian, tahap penelitian, dan tahap pasca penelitian. Pada tahap pra penelitian langkah yang dilakukan yaitu koordinasi dengan pihakpihak terkait ijin penelitian, pengambilan data jumlah penderita kasus dan kontrol di RSUD Tugurejo, menyusun rencana penelitian, menentukan besar sampel yang akan diteliti, mengurus perizinan, menyiapkan instrumen berupa kuesioner penelitian untuk mengumpulkan data primer. Pada tahap penelitian langkah yang dilakukan yaitu menyeleksi responden berdasarkan kriteria inklusi dan eksklusi, meminta kesediaan subjek penelitian untuk mengikuti penelitian, pengisian kuesioner, serta mendokumentasikan kegiatan penelitian dalam bentuk foto. Sementara pada tahap pasca penelitian dilakukan pengolahan data dengan bantuan komputer untuk memudahkan dalam analisis data, menyusun hasil penelitian, dan menarik kesimpulan.

Teknik pengolahan data meliputi editing, coding, skoring, tabulasi, dan entry. Data diolah dan dianalisis dengan komputer. Analisis univariat disajikan dalam bentuk tabel distribusi frekuensi dan prosentase dari masing-masing variabel baik variabel bebas maupun terikat. Sementara analisis bivariat dengan menggunakan uji statistik chi square.

\section{HASIL DAN PEMBAHASAN}

Rumah Sakit Umum Daerah Tugurejo merupakan rumah sakit kelas B milik pemerintah provinsi Jawa Tengah yang terletak di Kecamatan Ngaliyan, Kota Semarang. Salah satu kasus yang menjadi perhatian di klinik spesialis mata RSUD Tugurejo Semarang adalah masalah katarak termasuk katarak senilis.

Variabel yang diteliti dalam penelitian ini meliputi umur, jenis kelamin, tingkat pendidikan, tingkat penghasilan, riwayat keluarga katarak, kebiasaan merokok, lama terpapar sinar matahari, dan riwayat hipertensi.

Variabel umur dikategorikan menjadi berisiko jika berumur $\geq 60$ tahun dan tidak 
Aini N.A. dan Yunita D.P.S. / Katarak Senilis / HIGEIA 2 (2) (2018)

Tabel 1. Distribusi Karakteristik Responden

\begin{tabular}{llrrrrrr}
\hline \multicolumn{1}{c}{ Variabel } & \multicolumn{1}{c}{ Kategori } & Kasus & \multicolumn{1}{c}{$\%$} & Kontrol & \multicolumn{1}{c}{$\%$} & Jumlah & $\%$ \\
\hline Umur & 40-50 Tahun & 1 & 2,2 & 23 & 51,1 & 24 & 26,7 \\
& 51-60 Tahun & 15 & 33,4 & 17 & 37,8 & 32 & 35,5 \\
& 61-70 Tahun & 18 & 40 & 5 & 11,1 & 23 & 25,6 \\
& >71 Tahun & 11 & 24,4 & 0 & 0 & 11 & 12,2 \\
\hline Tingkat & Tidak Tamat SD & 7 & 15,6 & 3 & 6,7 & 10 & 11,1 \\
Pendidikan & Tamat SD & 13 & 28,9 & 7 & 15,6 & 20 & 22,2 \\
& Tamat SMP & 12 & 26,6 & 5 & 11,1 & 17 & 19 \\
& Tamat SMA & 9 & 20 & 22 & 48,8 & 31 & 34,4 \\
& Diploma/Sarjana & 4 & 8,9 & 8 & 17,8 & 12 & 13,3 \\
\hline
\end{tabular}

berisiko jika berumur $<60$ tahun. Variabel jenis

kelamin dikategorikan perempuan dan laki-laki.

Variabel tingkat pendidikan dikategorikan redah

(tidak tamat SD, tamat SD dan SMP) dan tinggi

(SMA dan perguruan tinggi). Variabel tingkat penghasilan dikategorikan rendah $(<\mathrm{UMR}$ Rp.2.125.000,-) dan tinggi ( $(\mathrm{UMR}$ Rp.2.125.000,-). Variabel riwayat keluarga katarak dikategorikan ada dan tidak ada. Variabel kebiasaan merokok yaitu riwayat responden melakukan aktifitas menghisap rokok secara rutin sedikitnya satu batang perhari selama sekurang-kurangnya 1 tahun. Variabel merokok dikategorikan ya dan tidak. Variabel lama terpapar sinar matahari dikategorikan terpapar jika $\geq 6$ jam perhari dan tidak terpapar jika $<6$ jam perhari. Variabel hipertensi dikategorikan hipertensi dan tidak hipertensi.

Tabel 1. Menunjukkan distribusi karakteristik responden berdasarkan usia dan tingkat pendidikan. Distribusi karakteristik responden berdasarkan usia yakni sebanyak 32 $(35,5 \%)$ responden berusia 51-60 tahun, sebanyak $24(26,7 \%)$ responden berusia 40-50 tahun, sebanyak $23(25,6 \%)$ responden berusia 61-70 tahun, serta sebanyak $11 \quad(12,2 \%)$ responden berusia $>71$ tahun. Distribusi karakteristk responden berdasarkan tingkat pendidikan yakni sebanyak $31 \quad(34,4 \%)$ responden tamat SMA, sebanyak $20(22,2 \%)$ responden tamat SD, sebanyak $17 \quad(19 \%)$ responden tamat SMP, sebanyak $12(13,3 \%)$ diploma/ sarjana, dan sebanyak $10(11,1 \%)$ responden tidak tamat $\mathrm{SD}$.

Tabel 2. Menunjukkan analisis bivariat yakni analisis hubungan antara variabel bebas dan variabel terikat. Hasil analisis bivariat yang dilakukan pada variabel umur menunjukkan secara statistik bahwa umur berhubungan dengan kejadian katarak senilis. Hasil uji chi square diperoleh nilai $\mathrm{p}=0,000<0,05$ dengan OR sebesar 12,02 dan 95\%CI=4,32-33,46, maka dapat diketahui bahwa responden yang berumur $\geq 60$ tahun 12,02 kali lebih berisiko menderita katarak senilis dibandingkan responden yang berusia $<60$ tahun. Menurut Michael (2011) Makin bertambah usia seseorang, protein lensa mengalami proses non-enzimatik, perkembangan genetik yang dapat meningkatkan kerentanan terhadap proses oksidasi, perubahan susunan molekul lensa dan peningkatan penghamburan cahaya. Lensa manusia yang tumbuh sepanjang hidup menyebabkan inti lensa terkena pengaruh tersebut dalam jangka waktu yang lama dan berisiko mengalami kerusakan oksidatif yang akan meningkat pada usia dekade keempat. Akibatnya, transparansi lensa berkurang dan inti lensa menjadi lebih kaku, sehingga menyebabkan kesulitan dalam kemampuan akomodasi mata yang dapat memperberat dalam pembentukan katarak.

Data di lapangan menunjukkan bahwa jumlah penderita katarak senilis dengan umur $\geq$ 60 tahun sebanyak 31 orang (68,9\%) lebih banyak dibandingkan dengan responden yang tidak menderita katarak senilis sebanyak 7 orang $(15,6 \%)$. Sedangkan penderita katarak senilis dengan umur $<60$ tahun sebanyak 14 orang $(31,1 \%)$ lebih sedikit dibandingkan dengan responden yang tidak menderita katarak senilis sebesar 38 (84,4\%). Hal ini menunjukkan bahwa usia mempengaruhi katarak senilis. Banyak responden yang mengeluhkan penglihatan mulai kabur dan tidak dapat melihat dengan jelas lagi pada usia yang semakin tua. Penelitian ini sejalan dengan penelitian Hadini (2016) yang menunjukkan ada hubungan antara umur dengan kejadian katarak senilis di RSU Bahteramas. Penelitian Handini menjelas- 
Aini N.A. dan Yunita D.P.S. / Katarak Senilis / HIGEIA 2 (2) (2018)

Tabel 2. Distribusi Analisis Bivariat

\begin{tabular}{|c|c|c|c|c|c|c|c|c|c|c|}
\hline \multirow[t]{3}{*}{ No } & \multirow[t]{3}{*}{ Variabel } & \multirow[t]{3}{*}{ Kategori } & \multicolumn{4}{|c|}{ Frekuensi (n) } & \multirow{2}{*}{\multicolumn{2}{|c|}{ Jumlah }} & \multirow{3}{*}{$\begin{array}{c}\text { OR } \\
(95 \% \mathrm{CI})\end{array}$} & \multirow{3}{*}{$\begin{array}{c}p- \\
\text { value }\end{array}$} \\
\hline & & & \multicolumn{2}{|c|}{ Kasus } & \multicolumn{2}{|c|}{ Kontrol } & & & & \\
\hline & & & $\mathrm{N}$ & $\%$ & $\mathrm{~N}$ & $\%$ & $\mathrm{~N}$ & $\%$ & & \\
\hline \multirow[t]{2}{*}{1.} & \multirow[t]{2}{*}{ Umur } & $\geq 60$ tahun & 31 & 68,9 & 7 & 15,6 & 38 & 42,2 & 12,02 & \multirow[t]{2}{*}{0,00} \\
\hline & & $<60$ tahun & 14 & 31,1 & 38 & 84,4 & 52 & 57,8 & $(4,32-33,46)$ & \\
\hline \multirow[t]{2}{*}{2.} & \multirow[t]{2}{*}{ Jenis Kelamin } & Perempuan & 21 & 46,7 & 19 & 42,2 & 40 & 44,4 & & \multirow[t]{2}{*}{0,83} \\
\hline & & Laki-Laki & 24 & 53,3 & 26 & 57,8 & 50 & 55,6 & - & \\
\hline \multirow[t]{2}{*}{3.} & Tingkat & Rendah & 32 & 71,1 & 15 & 33,3 & 47 & 52,2 & 4,92 & \multirow[t]{2}{*}{0,00} \\
\hline & pendidikan & Tinggi & 13 & 28,9 & 30 & 66,7 & 43 & 47,8 & $(2,01-12,04)$ & \\
\hline \multirow[t]{2}{*}{4.} & Tingkat & Rendah & 29 & 64,4 & 17 & 46 & 46 & 51,1 & 2,98 & \multirow[t]{2}{*}{0,02} \\
\hline & Penghasilan & Tinggi & 16 & 35,6 & 28 & 44 & 44 & 48,9 & $(1,26-7,04)$ & \\
\hline \multirow[t]{2}{*}{5.} & Riwayat & Ada & 12 & 26,7 & 8 & 17,8 & 20 & 22,2 & & \multirow[t]{2}{*}{0,45} \\
\hline & $\begin{array}{l}\text { Keluarga } \\
\text { Katarak }\end{array}$ & Tidak Ada & 33 & 73,3 & 37 & 82,2 & 70 & 77,8 & - & \\
\hline \multirow[t]{2}{*}{6.} & Kebiasaan & Ya & 17 & 37,8 & 23 & 51,1 & 40 & 44,4 & & \multirow[t]{2}{*}{0,29} \\
\hline & Merokok & Tidak & 28 & 62,2 & 22 & 48,9 & 50 & 55,6 & - & \\
\hline \multirow[t]{2}{*}{7.} & Lama Terpapar & $\geq 6$ jam perhari & 22 & 48,9 & 11 & 24,4 & 33 & 36,7 & 2,96 & \multirow[t]{2}{*}{0,02} \\
\hline & Sinar Matahari & $<6$ jam perhari & 23 & 51,1 & 34 & 75,6 & 57 & 63,3 & $(1,21-7,25)$ & \\
\hline \multirow[t]{2}{*}{8.} & Hipertensi & Hipertensi & 26 & 57,8 & 15 & 33,3 & 41 & 45,6 & 2,74 & \multirow[t]{2}{*}{0,03} \\
\hline & & $\begin{array}{l}\text { Tidak } \\
\text { Hipertensi }\end{array}$ & 19 & 42,2 & 30 & 66,7 & 49 & 54,4 & $(1,16-6,45)$ & \\
\hline
\end{tabular}

-kan bahwa semakin meningkatnya usia, maka estrogen bertanggungjawab dalam pembentukan sifat lensa sebagai salah satu organ tubuh juga akan ikut berubah. Perubahan yang terjadi salah satunya adalah meningkatnya kemampuan lensa untuk menghamburkan cahaya matahari. Tidak hanya pada lensa, penyebaran cahaya matahari juga terjadi secara intraokular, dan ini juga meningkat secara eksponensial sesuai dengan peningkatan usia. Perubahan ini secara nyata dimulai dari usia 40 tahun, kemudian meningkat hingga 2 kali lipat saat usia 65 tahun, dan mencapai 3 kali lipat pada usia 77 tahun (Berg, 2007). Hasil penelitian ini diperkuat oleh penelitian Sonowal (2013) di India yang menunjukkan bahwa prevalensi katarak senilis meningkat dengan pertambahan usia, sebagian besar berusia $\geq 60$ tahun $(90,81 \%)$, diikuti dengan umur 50-59 tahun (31,46\%), serta prevalensi terendah pada rentang umur 40-49 tahun $(10,38 \%)$.

Berdasarkan hasil penelitian diketahui bahwa tidak ada hubungan antara jenis kelamin dengan kejadian katarak senilis di RSUD Tugurejo Kota Semarang ( $p$ value $=0,83$ ). Menurut Andjelic (2012) bahwa hormon estrogen pada wanita mungkin mempengaruhi pembentukan katarak. Hormon ovarian meningkatkan katarak yang didinduksi radiasi. Endogen utama estrogen, ß-estradiol memiliki mitogenik dan efek anti-oksidatif pada konsentrasi fisiologis, sedangkan tingkat farmakologi menginduksi stres oksidatif dan bertindak proapoptosis dalam lensa. Suplemen hormon percobaan menunjukkan bahwa

katarak.

Perbedaan hasil dalam penelitianini disebabkan karena perbedaan tingkat hormon dan konsentrasi metabolit terhadap kerentanan individu dalam pembentukan katarak. Hal ini sesuai dengan Zhang (2003) menyebutkan bahwa prevalensi katarak meningkat dengan bertambahnya usia baik laki-laki maupun perempuan. Hormon seks tidak dapat menjelaskan kecenderungan ini. Hal ini dimungkinkan adanya riwayat genetik yang mengatur terjadinya katarak senilis atau mungkin protein pada lensa secara bertahap memiliki berat molekul yang tinggi, sehingga menyebabkan terjadinya kekeruhan lensa. Perbedaan tingkat hormon dan konsentrasi metabolit menghasilkan kerentanan yang berbeda dalam pembentukan katarak. Oleh karena itu, kadar hormon seks dapat dianggap sebagai faktor risiko kataraktogenesis, namun bukan merupakan faktor utama.

Hasil penelitian ini berbeda dengan penelitian sebelumnya yang dilakukan oleh Hadini (2016), Mo'otapu (2015) yang menunjukkan bahwa terdapat hubungan antara jenis kelamin perempuan dengan kejadian katarak. Perbedaan hasil penelitian ini dikarenakan proporsi penderita katarak berjenis kelamin laki-laki lebih mendominasi dibandingkan perempuan. Selain itu adanya perbedaan kriteria inklusi maupun eksklusi yang berpengaruh terhadap hasil penelitian.

Hasil analisis bivariat menunjukkan 
tingkat pendidikan berhubungan dengan kejadian katarak senilis di RSUD Tugurejo Kota Semarang. Hasil uji chi square diperoleh nilai $\mathrm{p}=0,000<0,05$ dengan OR sebesar 4,92 dan $95 \% \mathrm{CI}=2,01-12,04$, maka dapat diketahui bahwa responden dengan tingkat pendidikan rendah 4,92 kali lebih berisiko menderita katarak senilis dibandingkan responden dengan tingkat pendidikan tinggi. Menurut Tana (2009) pendidikan yang kurang dapat menyebabkan kurangnya pengetahuan dan kesadaran mengenai penyakit katarak dan pengobatannya.

Data di lapangan menunjukkan bahwa responden penderita katarak dengan pendidikan rendah sebanyak 32 orang $(71,1 \%)$ lebih banyak dibandingkan dengan bukan penderita katarak yaitu 15 orang $(33,3 \%)$. Sedangkan responden bukan penderita katarak dengan pendidikan tinggi yaitu 30 orang $(66,7 \%)$ lebih banyak dibandingkan dengan responden penderita katarak sebanyak 13 orang (28,9\%). Pendidikan masyarakat yang rendah akan berdampak pada tidak adanya pemahaman dan kesadaran akan penyakit katarak. Dari beberapa wawancara dengan responden, mereka mengaku tidak pernah tahu sebelumnya mengenai penyakit katarak, gejala katarak serta pencegahannya. Mereka juga cenderung memeriksakan diri setelah penglihatan dirasa cukup mengganggu aktifitas sehari-hari. Hasil ini sesuai dengan hasil Riset Kesehatan Dasar (RISKESDAS) Indonesia tahun 2013 yang menunjukkan bahwa terdapat tiga terbanyak alasan penderita katarak belum operasi yaitu 51,6\% karena tidak mengetahui menderita katarak, 11,6\% karena tidak mampu membiayai dan $8,1 \%$ karena takut operasi.

Penelitian ini sejalan dengan penelitian yang dilakukan oleh Laila (2017) menunjukkan bahwa terdapat hubungan antara pendidikan dengan kejadian katarak senilis di daerah pesisir, hal ini dikarenakan pendidikan belum menjadi kebutuhan yang penting apalagi kondisi sarana dan prasarana yang tidak mendukung. Selain itu, faktor ekonomi juga menjadi alasan rendahnya tingkat pendidikan. Meskipun tidak ditemukan hubungan langsung antara tingkat pendidikan dan katarak. Namun, pendidikan rendah dapat berpengaruh pada penghasilan yang akan mempengaruhi status nutrisi seseorang. Selain itu, rendahnya pendidikan menjadikan responden memiliki pekerjaan sebagai nelayan, buruh, dan pedagang jalanan dengan paparan sinar matahari yang berdampak pada pembentukan katarak. Penelitian Bae (2015) berdasarkan Korea national health nutrition examnation survey menunjukkan bahwa terdapat hubungan antara tingkat pendidikan dengan kejadian katarak senilis. Adanya hubungan dalam penelitian Bae dikarenakan orang dengan pendidikan rendah mungkin mengalami kesulitan memperoleh informasi tentang risiko kesehatan.

Hasil analisis bivariat menunjukkan bahwa tingkat penghasilan berhubungan dengan kejadian katarak senilis di RSUD Tugurejo Kota Semarang .Hasil uji chi square diperoleh nilai $\mathrm{p}=0,02<0,05$ dengan OR sebesar 2,98 dan 95\% CI=1,26-7,04, maka dapat diketahui bahwa responden dengan tingkat penghasilan rendah 2,98 kali lebih berisiko menderita katarak senilis dibandingkan responden dengan tingkat penghasilan tinggi. Hal ini sesuai dengan Andayani (2017) bahwa tingkat kesehatan pada sebagian responden ditentukan oleh pendapatan keluarga. Uang dapat dipakai untuk memperoleh pelayanan kesehatan, dan perbaikan faktor dari lingkungan, sehingga membantu mencegah suatu penyakit.

Penelitian ini menunjukkan responden penderita katarak dengan penghasilan rendah sebanyak 29 orang $(64,4 \%)$ lebih banyak dibandingkan dengan bukan penderita katarak sebanyak 17 orang (37,8\%). Sedangkan responden bukan penderita katarak dengan penghasilan tinggi sebanyak 28 orang $(62,2 \%)$ lebih banyak dibandingkan dengan penderita katarak sebanyak 16 orang $(35,6 \%)$. Berdasarkan data di lapangan menyatakan bahwa responden yang berpenghasilan rendah berkaitan dengan pendidikan responden yang rendah. Pendidikan responden yang rendah mempengaruhi pekerjaan responden yang banyak di bidang informal dengan penghasilan yang kurang menentu, sehingga kurang terpenuhi dalam asupan nutrisi serta kesulitan 
dalam memperoleh informasi kesehatan. Selain itu, meskipun pemerintah telah menyediakan jaminan kesehatan nasional (JKN) secara gratis bagi masyarakat kurang mampu, namun belum bisa mengcover akses layanan kesehatan dikarenakan kurangnya dukungan keluarga, jarak rumah yang jauh dari sarana pelayanan kesehatan yang menyebabkan ongkos transportasi menjadi mahal.

Hasil penelitian ini sejalan dengan penelitian yang dilakukan oleh Sonowal (2013) yang menunjukkan adanya hubungan yang signifikan antara status sosial ekonomi rendah dengan kejadian katarak. Sebagian besar penderita katarak mempunyai status ekonomi rendah yaitu berjumlah $33,49 \%$, status ekonomi paling rendah sebanyak $19,59 \%$, dan sebanyak $16 \%$ responden mempunyai status ekonomi kelas menengah. Hasil penelitian ini didukung oleh Wesolosky (2015) bahwa responden dengan sosial ekonomi rendah memiliki katarak yang lebih parah. Status sesioekonomi seseorang mempengaruhi kesehatan, hal ini meliputi pendidikan, pendapatan, status keluarga, dan lingkungan sosial yang berperan dalam pengembangan permasalahan kesehatan seperti katarak.

Hasil analisis bivariat menunjukkan bahwa riwayat keluarga katarak tidak berhubungan dengan kejadian katarak senils di RSUD Tugurejo Kota Semarang ( $p$ value= 0,45). Menurut Abraham (2006) bahwa gen berkontribusi dalam mekanisme kataraktogenesis yang pada akhirnya menghasilkan produk gen yang selanjutnya informasi tersebut dapat membantu dalam mengidentifikasi individu yang memiliki kecenderungan lebih rentan terhadap faktor risiko katarak. Ketidaksesuaian hasil penelitian dengan teori dikarenakan responden tidak mengetahui tentang adanya riwayat sakit katarak pada keluarga sebelumnya, hal ini disebabkan karena tidak adanya pemeriksaan mata sebelumnya, terdapat responden yang telah memisahkan diri dari keluarga sejak kecil, serta terdapat beberapa responden yang mengaku mempunyai keluarga dengan gejala katarak, namun tidak pernah memeriksakan diri ke fasilitas pelayanan kesehatan, jadi diagnosis katarak tidak dapat ditegakkan secara pasti.

Hasil penelitian menunjukkan responden katarak yang mempunyai riwayat keluarga sebelumnya ada katarak sebanyak 12 orang $(26,7 \%)$ lebih tinggi dibandingkan responden bukan katarak yaitu 8 orang $(17,8 \%)$. Sedangkan responden bukan penderita katarak dengan tidak adanya riwayat keluarga katarak sebelumnya sebanyak 37 orang (82,2\%) lebih banyak dibandingkan dengan penderita katarak sebanyak 33 orang $(73,3 \%)$.

Hasil penelitian ini berbeda dengan penelitian Heidar (2015) di Iran, Sonowal (2013) di India yang menunjukkan adanya hubungan yang signifikan antara adanya riwayat keluarga yang pernah sakit katarak dengan kejadian katarak senilis. Adanya hubungan ini dimungkinkan karena proporsi responden dengan riwayat keluarga katarak lebih tinggi dibandingkan responden tanpa adanya riwayat katarak dalam keluarga, akses layanan kesehatan yang sudah memadai, serta adanya kesadaran tentang kesehatan.

Hasil analisis bivariat menunjukkan bahwa kebiasaan merokok tidak berhubungan dengan kejadian katarak senilis di RSUD Tugurejo Kota Semarang ( $p$ value $=0,29$ ). Secara teori, merokok dapat menyebabkan katarak dengan beberapa mekanisme biologis diantaranya, yang pertama kerusakan oksidatif memiliki peran utama dalam pembentukan katarak. Merokok menyebabkan pertambahan zat oksidatif melalui aktifitas radikal bebas, oksidasi dan peroksidasi lipid. Di sisi lain, merokok dapat menyebabkan stres oksidatif (keadaan dimana jumlah radikal bebas dalam tubuh melebihi kapasitas tubuh untuk menetralkannya) secara tidak langsung pada lensa melalui penipisan antioksigen endogen, seperti vitamin $\mathrm{C}$, vitamin $\mathrm{E}$, dan b-karoten. Kedua, tembakau mengandung logam berat seperti kadmium, timbal, dan tembaga yang menumpuk dalam lensa menyebabkan kerusakan secara langsung. Ketiga, kadar sianida dan aldehid naik dalam darah perokok, kemudian aldehida dan isosianat yang terbentuk dari sianida dapat mengubah struktur protein 
lensa yang menyebabkan terjadinya kekeruhan dalam lensa yang berdampak dalam pembentukan katarak (Ye, 2012).

Perbedaan hasil penelitian ini dengan teori disebabkan merokok berkaitan dengan jenis kelamin, dari 24 penderita katarak berjenis kelamin laki-laki, sebanyak $29 \%$ menyatakan tidak memiliki kebiasaan merokok. Sedangkan dari 21 responden katarak dengan jenis kelamin perempuan, $100 \%$ menyatakan tidak pernah merokok, bahkan mereka menganggap merokok bagi wanita adalah sesuatu yang tidak baik, dan beberapa responden lebih menyukai menginang dibandingkan merokok. Selain itu, dari total 90 responden, responden yang tidak memiliki kebiasaan merokok sebanyak 50 orang $(55,6 \%)$ lebih banyak dibandingkan memiliki kebiasaan merokok yaitu 40 orang $(44,4 \%)$. Hal ini sesuai dengan hasil Riset Kesehatan Dasar (RSKESDAS) tahun 2013 yang menunjukkan bahwa Provinsi Jawa Tengah khususnya Kota Semarang lebih dari setengah penduduknya tidak merokok, yang terdiri dari 4,8\% mantan perokok dan $71,5 \%$ bukan perokok.

Hasil penelitian ini tidak sejalan dengan penelitian Heidar (2015), Hadini (2016) yang menunjukkan adanya hubungan antara merokok dengan kejadian katarak. Perbedaan hasil penelitian ini disebabkan karena jumlah responden yang merokok lebih besar dibandingkan dengan jumlah responden yang tidak merokok, adanya perbedaan karakteristik responden, serta adanya variasi acak pengambilan sampel dalam populasi yang mempengaruhi hasil penelitian.

Hasil analisis bivariat menunjukkan bahwa lama terpapar sinar matahari berhubungan dengan kejadian katarak senilis di RSUD Tugurejo Kota Semarang .Hasil uji chi square diperoleh nilai $\mathrm{p}=0,02<0,05$ dengan $\mathrm{OR}$ sebesar 2,96 dan $95 \% \mathrm{CI}=1,21-7,25$, maka dapat diketahui bahwa responden yang terpapar sinar matahari $\geq 6$ jam perhari 2,96 kali lebih berisiko menderita katarak senilis dibandingkan dengan responden dengan lama terpapar sinar matahari $<6$ jam perhari. Hal ini sesuai dengan Tana (2006) yang mengatakan bahwa pejanan sinar dengan panjang gelombang yang berdekatan dengan panjang gelombang ultraviolet/UVB 300-400 $\mathrm{nm}$ berhubungan dengan terjadinya perubahan kimia dan fisik pada protein dan sel epitel lensa. Lensa mata rapuh terhadap kerusakan karena lensa tidak memiliki sensor panas dan mempunyai mekanisme penyalur panas yang buruk. Pejanan pada radiasi UVB bahkan tingkat terendah yang berasal dari matahari kadang-kadang meningkatkan risiko katarak dan dicurigai berhubungan dengan terjadinya katarak jenis kortikol. Hasil Penelitian Tang (2015) menunjukkan bahwa aktivitas luar ruangan lebih lama berkorelasi dengan risiko terjadinya katarak jenis kortikol meningkat sebesar 1,1\% ketika paparan UV-B secara kumulatif bertambah setiap tahun. Beberapa responden yang berusia lebih tua yang melakukan sedikit aktifitas di luar ruangan lebih memungkinkan berisiko terkena katarak jenis kortikol dibandingkan responden usia muda yang lebih banyak beraktifitas di luar, hal ini dikarenakan pada responden dengan usia tua memiliki paparan UV-B dari tahun ke tahun yang terus bertambah.

Hasil penelitian menunjukkan penderita katarak dengan paparan lebih dari 6 jam perhari yaitu 22 orang $(48,9 \%)$ lebih banyak dibandingkan dengan responden bukan penderita katarak yaitu 11 orang $(24,4 \%)$. Sedangkan penderita bukan katarak dengan paparan kurang dari 6 jam perhari sejumlah 34 orang $(75,6 \%)$ lebih banyak dibandingkan dengan responden penderita katarak yaitu 23 orang $(51,1 \%)$. Data di lapangan menunjukkan responden katarak bekerja dengan paparan matahari yang cukup lama, mereka bekerja dari pagi sampai sore di lapangan. Mereka bekerja sebagai buruh bangunan, supir, pedagang, petani, tukang kebun, tukang parkir yang berhubungan langsung dengan paparan sinar matahari. Selain itu, banyak responden yang mengaku tidak selalu memakai alat pelindung diri saat terpapar sinar matahari.

Responden yang bekerja dibawah terik sinar matahari langsung seperti buruh tani, mereka bekerja dari pukul 06.00 pagi sampai dengan pukul 05.00 sore, selama bekerja mereka menggunakan caping untuk meminimalisir 
masuknya sinar matahari ke mata. Pekerja lapangan di bidang yang lain seperti buruh bangunan, tukang parkir, tukang kebun dapat terpapar sinar matahari dengan mudah, namun saat bekerja mereka hanya memakai APD berupa topi dan tidak menggunakan kacamata gelap. Selain itu, terdapat responden yang bekerja sebagai supir. Pada saat bekerja, sinar matahari dapat masuk melalui kaca mobil yang tidak diproteksi terhadap UV. Pantulan sinar matahari ini dapat diminimalisir dengan kaca mobil yang diproteksi terhadap sinar matahari berupa kaca film atau penggunaan kacamata gelap. Akan tetapi responden tidak menggunakan salah satu atau keduanya. Terdapat responden yang bekerja sebagai pedagang, yaitu pedagang sayur keliling, pedagang obat keliling, namun pada saat bekerja responden tidak memakai kacamata gelap. Aktifitas responden yang lain selain bekerja seperti seperti berkendara motor, berjalan, dll yang secara langsung terkena paparan sinar matahari, sebagian besar tidak memakai APD seperti kacamata gelap, helm dengan kaca anti UV saat bekendara, dan topi dengan pinggiran lebar bagi pejalan kaki.

Berdasarkan rekap data responden yang memakai alat pelindung diri saat bekerja sebanyak 36 orang (40\%). Pada kelompok kontrol yang memakai APD saat beraktifitas di bawah terik sinar matahari sebanyak 19 orang $(42,2 \%)$ lebih banyak dibandingkan responden kasus sebanyak 17 orang (37,8\%). Jenis APD yang banyak dipakai responden adalah topi. Sedangkan, pemakaian kacamata gelap anti UV hanya berjumlah 11 orang $(12,2 \%)$. Bahaya akan sinar ultraviolet ini belum banyak diketahui oleh responden, sehingga perlu diadakannya penyuluhan atau promosi kesehatan untuk menggunakan alat pelindung diri saat beraktfitas di bawah sinar matahari.

Hasil penelitian ini sejalan dengan penelitian yang dilakukan oleh Penelitian Heidar (2015), Sonowal (2013) yang menunjukkan ada hubungan antara lama terpapar sinar matahari dengan kejadian katarak senilis. Adanya hubungan dikarenakan sebagian besar responden katarak senilis terkena paparan sinar matahari saat bekerja. Hasil penelitian didukung oleh Sinha (2009) yang menyatakan bahwa pekerjaan berhubungan dengan paparan sinar ultraviolet langsung yang berpengaruh dalam pembentukan katarak. Sinar ultravolet yang berasal dari sinar matahari akan diserap oleh protein lensa dan kemudian akan menimbulkan reaksi fotokimia sehingga terbentuk radikal bebas atau spesies oksigen yan bersifat sangat reaktif. Reaksi tersebut akan mempengaruhi struktur protein lensa, sehingga menyebabkan kekerukan lensa yang disebut dengan katarak.

Hasil analisis bivariat menunjukkan bahwa riwayat hipertensi berhubungan dengan kejadian katarak senilis di RSUD Tugurejo Kota Semarang. Hasil uji chi square diperoleh nilai $\mathrm{p}=0,03<0,05$ dengan $\mathrm{OR}$ sebesar 2,74 dan 95\% CI $=1,16-6,45$, maka dapat diketahui bahwa responden yang pernah menderita hipertensi 2,74 kali lebih berisiko menderita katarak senilis dibandingkan dengan responden yang tidak pernah menderita hipertensi. Hal ini sesuai dengan $\mathrm{Yu}$ (2014) yang mengatakan bahwa hipertensi menyebabkan peningkatan sitokinin inflamasi seperti tumor necrosis factor-alpha (TNF- $\alpha$ ), interleukin-6 (IL-6). Selain itu, peningkatan tingkat protein C-reaktif (CRP) telah terdeteksi saat tekanan darah individu meningkat. Telah diketahui bahwa katarak berhubungan erat dengan inflamasi sistemik yang hebat, karena hipertensi terlibat dalam jalur patologis perkembangan katarak melalui mekanisme inflamasi. Selain itu, mekanisme hipertensi menyebabkan katarak senilis dengan cara mempengaruhi perubahan struktur protein lensa menyebabkan ketidakseimbangan osmotik dalam lensa yang mengakibatkan terjadinya katarak senilis.

Hasil penelitian ini menunjukkan penderita katarak yang menderita hipertensi sebanyak 26 orang $(57,8 \%)$ lebih banyak dibandingkan dengan responden bukan penderita katarak yaitu 15 orang $(33,3 \%)$. Sedangkan responden bukan penderita katarak yang tidak menderta hipertensi sebanyak 30 orang $(66,7 \%)$ lebih banyak dibandingkan dengan responden penderita katarak sebanyak 
19 orang (42,2\%). Data dilapangan menunjukkan bahwa tekanan darah responden bersifat tidak tetap, kadang tekanan darah naik, terkadang menurun. Tekanan darah ini dikaitakan dengan adanya riwayat hipertensi dalam keluarga, stress, jarang berolahraga serta usia responden penderita katarak yang tergolong lansia.

Hasil penelitian ini sejalan dengan penelitan Heidar (2015) menyatakan adanya hubungan yang bermakna antara hipertensi dengan kejadian katarak senilis di Iran. Penelitian Heidar menunjukkan bahwa penderita katarak senilis yang menderita tekanan darah tinggi sebanyak 27,1\% lebih tinggi dibandingkan non katarak sebesar 8,9\%.

\section{PENUTUP}

Berdasarkan hasil penelitian dan analisis data yang telah dilakukan dapat disimpulkan bahwa terdapat hubungan antara umur, tingkat pendidikan, tingkat penghasilan, lama terpapar sinar matahari, dan riwayat hipertensi dengan kejadian katarak senilis di RSUD Tugurejo Kota semarang ( $p$ value $<\alpha$ ), sedangkan tidak terdapat hubungan antara jenis kelamin, riwayat keluarga katarak, dan kebiasaan merokok dengan kejadian katarak senilis di RSUD Tugurejo Kota Semarang ( $p$ value $>\alpha$ ). Saran bagi peneliti yang akan melakukan penelitian dengan tema yang sama, diharapkan agar diharapkan agar mengembangkan penelitian dengan memperluas sampel penelitian, melakukan penelitian pada populasi yang seragam, atau membandingkan faktor risiko pada responden di daerah pegunungan dan di daerah pantai.

\section{DAFTAR PUSTAKA}

Abraham, A. G., Condon, N. G., \& Gower, E. W. 2006. The New Epidemiology of Cataract. Ophtalmology Clinics of North America, 19(4): $415-25$.

Andayani., \& Fibriana, AI. 2018. Kejadian Demam Tifoid di Wilayah Kerja Puskesmas Karangmalang. HIGEIA, 2 (1): 57-68.
Andjelic, S., \& Hawlina, M. 2012. Cataractogenesis. Zdrav Vestn, 81(I): I-122-32.

Bae, J. H., Shin, D. P., Lee, S. C., \& Hwang I. C. 2015. Sodium Intake and Socioeconomic Status as Risk Factors for Development of Age-Related Cataracts: The Korea national health and Nutrition Examination Survey. PLOS ONE, 10 (8): e0136218.

Berg, T., Rijn, LJ., Michael, R, dst. 2007. Straylight Effects with Aging and Lens Extraction. American Journal of Ophthalmology, 144 (3): 358-363.

Bhardwaj, A. 2016. Incidence of Cataract in Tertiary Care Hospital. Indian Journal of Applied Research, 6 (1): 2249-555x.

Dinas Kesehatan Kota Semarang. 2016. Laporan Sub Bidang Pelayanan Kesehatan tentang Angka Kejadian Katarak Senilis Tahun 2013-2016. Semarang: Dinas Kesehatan Kota Semarang

Hadini, MA., Eso, A., \& Wicaksono S. 2016. Analisis Faktor Risiko yang Berhubungan dengan Kejadian Katarak Senilis di RSU Bahteramas Tahun 2016. Jurnal Medula, 3 (2): 2443-0218.

Heidar, F., Jamal F., \& Mohammad N. 2015. Comparison of Epidemiological Factors Between Patients with Senile Cataract and Controls Without Cataract. Open Science Journal of Clinical Medicine, 3(3): 86-89.

Kemenkes RI. 2007. Riset Kesehatan Dasar (RISKESDAS) tahun 2007. Kementrian Kesehatan RI: Jakarta.

Kemenkes RI. 2013. Riset Kesehatan Dasar (RISKESDAS) tahun 2013. Kementrian Kesehatan RI: Jakarta.

Kemenkes RI. 2014. Infodatin: Situasi Gangguan Penglihatan dan Kebutaan. Kementrian Kesehatan RI: Jakarta.

Laila, A., Raupong, I., \& Saimin, J. dkk. 2017. Analisis Faktor-Faktor Risiko Kejadian Katarak di Daerah Pesisir Kendari. Jurnal Medula, 4 (2): 2443-0218.

Michael, R., \& Bron, A. J. 2011. The ageing lens and cataract: a model of normal and pathological ageing. Philosophical Transactions of the Royal Society B: Biological Sciences, 366 (1568): 1278-1292.

Mo'otapu, A., Rompas, S., \& Bawotong, 2015. Faktor-Faktor yang Berhubungan dengan Kejadian Penyakit Katarak di Poli Mata RSUP Prof. Dr. R. D Kandou Manado. eJournal Keperawatan (e-Kp), 3 (2): 1-6 Nash, 
E. 2013. Cataracts. Sage Journal, 6 (9): 555562.

Robert, JE. 2011. Ultraviolet Radiation as a Risk Factor for Cataract and Macular Degeneration. Eye \& Contact Lens, 37(4): 246-249.

RSUD Tugurejo Kota Semarang. 2017. Catatan Rekam Medis RSUD Tugurejo tentang Angka Kejadian Katarak Senilis. Semarang: RSUD Tugurejo.

Sinha, R., Kumar, C., \& Titiyal, JS. 2009. Etiopathogenesis Of Cataract: Journal Review. Indian Journal Of Ophtalmology, 57 (3): 245-249.

Sonowal, S. K., Kuli, J. J., \& Gogoi G. 2013. A Study of Prevalence and Risk Factors of Senile Cataract in Tea Garden Community in Dibrugarh District, Assam, India. International Journal of Science and Research (IJSR), 5 (3): 2319-7064.

Tana, L. 2006. Faktor Risiko dan Upaya Pencegahan Katarak pada Kelompok Pekerja. Media Litbang Kesehatan, 16(1): 43-50.
Tana, L., Rif'ai, L., \& Ghani, L. 2009. Peranan pekerjaan Terhadap Kejadian Katarak pada Masyarakat Indonesia Riset Kesehatan Dasar 2007. Buletin Penelitian Kesehatan Supplement, 37 (9): 77-84.

Tang, Y., Ji, Y., Wang., X, dst. 2015. The Association of Outdoor Activity and AgeRelated Cataract in a Rural Population of Taizhou Eye Study: Phase 1 Report. PLOS ONE, 10 (8): e0135870.

Wesolosky, JD., \& Rudnisky, CJ. 2015. Reprint of: Relationship between Cataract Severity and Socioeconomic Status. Can J Ophtalmol, 50 (S1): S16-S22.

Ye, J., He, J., Wang, C., Wu, H, dst. 2012. Smoking and Risk of Age-Related Cataract: A Meta Analysis. IOVS, 53 (7): 3885-3895.

Yu, X., Lyu, D., Dong,X, He, J., \& Yao, K. 2014. Hipertensi and Risk of Cataract: A MetaAnalysis. PLOS ONE, 9 (12): e114012.

Zhang, XH., Sun, HM., Ji, J, dst. 2003. Sex Hormones and Their Receptors in Patients With Age Related Cataract. NCBI, 29(1):71-7 